PRACE NAUKOWE UNIWERSYTETU EKONOMICZNEGO WE WROCLAWIU

Wyzwania dla spójności Europy -

gospodarka, zrównoważony rozwój, konkurencyjność

ISSN 1899-3192

e-ISSN 2392-0041

\title{
Magdalena Wojarska
}

Uniwersytet Warmińsko-Mazurski w Olsztynie

e-mail: magdaw@uwm.edu.pl

\section{TYPOLOGIA GMIN \\ Z PUNKTU WIDZENIA DOŚWIADCZEŃ \\ W WYKORZYSTANIU FUNDUSZY UE}

\section{TYPOLOGY OF MUNICIPALITIES \\ FROM THE VIEWPOINT \\ OF EUROPEAN UNION FUNDS}

DOI: $10.15611 /$ pn.2017.466.25

JEL Classification: R58, R19

\begin{abstract}
Streszczenie: Artykuł ma charakter empiryczny, a jego celem jest próba identyfikacji typów gmin z punktu widzenia wybranych aspektów problematyki funduszy UE. Dane do analizy pochodziły z BDL, bazy Mojapolis.pl oraz badań przeprowadzonych w 2014 r. wśród skarbników gmin. Informacje te stanowiły podstawę klasyfikacji przeprowadzonej za pomocą uogólnionej metody EM. W jej wyniku zbiór 909 gmin podzielony został na trzy rozłączne, różnoliczne zbiory, tj. I, II i III. Średnio, największą wartością absorpcji funduszy UE na mieszkańca charakteryzowała się grupa III, a najniższą II.
\end{abstract}

Słowa kluczowe: fundusze UE, samorząd gminny, uogólniona metoda EM.

Summary: This is an empirical article, and its aim is to try to isolate the types of municipalities from the viewpoint of selected aspects of EU funds. The data were gathered from Local Data Bank, the database called "Mojapolis.pl" and also during the research conducted in 2014 among gminas' treasurers. This information was used to a group of Polish gminas by expectationmaximization method. As a result, a collection of 909 municipalities was divided into three sets which were separable and consisted of different numbers of elements. The groups differed with regard to value and structure of variables. On average, group III had the highest level of absorption of EU funds per capita in contrast to group II where the level was the lowest.

Keywords: EU funds, local government, Expectation-Maximization method.

\section{Wstęp}

Samorząd terytorialny stanowi system, instytucję i organizację o charakterze ekonomicznym, a istotą jego działalności jest świadczenie usług publicznych. Jako właściciel majątku i finansów zarządza dużymi zasobami i wykorzystuje je w dobrze poję- 
tym interesie publicznym [Wojciechowski 2012]. Głównym celem zarządzania finansami gminy jest realizacja zadań publicznych i społecznych oraz zapewnienie podstaw stabilnego i zrównoważonego rozwoju [Wakuła 2009]. Gminy, podobnie jak podmioty gospodarcze, borykają się z niewystarczającą ilością środków finansowych [Zawora 2014]. System zasilania samorządów w niezbędne fundusze wydaje się bowiem nieadekwatny do przypisanych im zadań, co zmusza je do poszukiwania zewnętrznych źródeł finansowania działalności, zwłaszcza inwestycyjnej [Wyszkowska 2011]. Ze względu na bezzwrotny charakter w centrum ich zainteresowania często pojawiają się środki z budżetu UE [Wyszkowska 2010]. Aktywność samorządu w ich pozyskiwaniu jest warunkowana przede wszystkim jego przygotowaniem instytucjonalnym i programowym oraz sytuacją budżetową zabezpieczającą niezbędny wkład własny, która z kolei determinowana jest potencjałem demograficznym i stanem gospodarki poszczególnych jednostek [Churski i in. 2016; Misiąg i in. 2013].

Obecnie fundusze UE są naturalnym elementem krajobrazu gospodarczego polskich gmin [Swianiewicz 2015]. W latach 2006-2014 jednostki te pozyskały łącznie 63 502,92 mln zł, co stanowiło 5,67\% ogółu ich dochodów budżetowych. Pieniądze te trafiały przede wszystkim do gmin miejskich $(59,16 \%)$ oraz do jednostek zlokalizowanych na obszarze województwa mazowieckiego (14,75\%) i śląskiego $(13,27 \%)$. $\mathrm{Na}$ drugim biegunie rankingu (z najmniejszą wartością wpływów) znalazły się gminy miejsko-wiejskie (17,57\%), a w ujęciu terytorialnym - samorządy należące do województwa opolskiego (1,99\%). Jednostkowo największym beneficjentem była Warszawa (4881,02 mln zł), najmniejszym natomiast usytuowana w województwie wielkopolskim gmina wiejska Komorniki (0,18 mln zł).

Ze względu na nierównomierny podział administracyjny kraju (różnica w liczbie gmin województwa mazowieckiego i opolskiego to aż 243 jednostki) oraz zróżnicowaną liczebność zbiorów według typów gmin, poprawne przeprowadzenie analizy wymaga relatywizacji danych. W przypadku niniejszych rozważań za punkt odniesienia przyjęto dwie wielkości: liczbę mieszkańców oraz dochody ogólem budżetów gmin.

Również i w tym ujęciu zbiorowość polskich gmin była bardzo zróżnicowana. W grupie tej można było bowiem spotkać jednostki, dla których omawiane źródło finansowania miało w latach 2006-2014 marginalne znaczenie (np. gmina Kaczory, Komorniki ${ }^{1}$ ), oraz takie, dla których środki z UE i innych programów zagranicznych stanowiły znaczny odsetek w dochodach ogółem (m.in. Uniejów, Ożarowice²). $\mathrm{W}$ analizowanym okresie najwyższym poziomem absorpcji funduszy w przeliczeniu na mieszkańca charakteryzowały się gminy z województwa pomorskiego (średnio $2275,23 \mathrm{zł}$ na osobę), natomiast najniższym z wielkopolskiego (999,41 zł).

Wśród wyróżniających się samorządów (tj. takich, w których wartość unijnego wsparcia przekroczyła 10 tys. zł na mieszkańca) znaleźli się przedstawiciele wszyst-

${ }^{1}$ W latach 2006-2014 udział środków pozyskanych przez samorząd gminy z UE i innych programów zagranicznych w dochodach budżetów ogółem w przypadku gminy Kaczory wyniósł 0,11\%, a gminy Komorniki 0,03\%.

${ }^{2}$ W gminie Uniejów było to $42,04 \%$, a w Ożarowicach $31,80 \%$. 
kich typów gmin. W grupie miast prym wiodły Krynica Morska (24 103,33 zł) i Jastarnia (11 931,97 zł), w gminach wiejskich dominowały Ożarowice (13 425,66 zł) i Ślemień (10 414,62 zł), a w miejsko-wiejskich - Uniejów (20 647,66 zł). Z kolei końcówkę zestawienia (z wartością środków europejskich poniżej 100 zł na osobę) utworzyło 6 gmin, a w tym trzy miasta (Pruszków - 87,92 zł, Garwolin - 86,59 zł i Piastów - 66,76 zł) oraz trzy gminy wiejskie (Wierzbno - 95,17 zł, Kaczory 24,22 zł i Komorniki 9,44 zł).

\section{Założenia metodyczne badań}

Artykuł ma charakter empiryczny, a jego celem jest próba identyfikacji typów gmin z punktu widzenia wybranych aspektów problematyki funduszy UE w latach 2007-2013. Szczególna uwaga została zwrócona na takie kwestie, jak: intensywność wykorzystania środków unijnych, tematyczne obszary koncentracji projektów europejskich, cele realizowanych przedsięwzięć, czynniki brane pod uwagę przy podejmowaniu decyzji o ubieganie się o dofinansowanie z UE oraz czynniki ułatwiające i utrudniające przygotowanie projektu oraz jego realizację.

Intensywność wykorzystania środków europejskich opisana została dwoma wskaźnikami: wartością dochodów pozyskanych przez gminy z UE i innych programów zagranicznych ${ }^{3} \mathrm{w}$ przeliczeniu na mieszkańca $\left(x_{1}\right)$ oraz udziałem dochodów pozyskanych przez gminy z UE i innych programów zagranicznych w dochodach ogółem $\left(x_{2}\right)$. Dane do ich wyznaczenia zaczerpnięto z Banku Danych Lokalnych oraz bazy stowarzyszenia Klon/Jawor (mojapolis.pl). Pozostałe informacje uwzględnione $\mathrm{w}$ analizie pochodziły $\mathrm{z}$ badań ankietowych przeprowadzonych wśród skarbników gmin na przełomie lutego i marca 2014 r. (badania pilotażowe w województwie warmińsko-mazurskim) oraz w IV kwartale 2014 r. (badania właściwe ${ }^{4}$ ). Z ogólnej liczby 2479 dostarczonych kwestionariuszy kompletne i prawidłowo wypełnione formularze otrzymano od 909 respondentów, co dało współczynnik zwrotu równy 36,7\% (najwyższą zwrotność uzyskano w woj. świętokrzyskim - 51,96\%, najniższą w opolskim - 22,54\%). Przy założeniu poziomu ufności 0,95 i szacowanej wielkości frakcji 0,5 błąd odpowiedzi z uzyskanej próby wyniósł 0,026 (w tym w gminach miejskich 0,063, wiejskich 0,034, miejsko-wiejskich 0,051).

Zmierzając do wyodrębnienia typów gmin, zgromadzony materiał empiryczny (pierwotny i wtórny) poddany został procedurze klasyfikacji za pomocą uogólnionej

${ }^{3}$ Według metodyki przyjętej w bazie Mojapolis.pl, Środki pozyskane z UE i innych programów zagranicznych oznaczają dochody budżetu gminy, dla których 4 cyfra paragrafu w klasyfikacji budżetowej dochodów, przychodów i środków pochodzących ze źródeł zagranicznych (zgodnie z Rozporządzeniami Ministra Finansów z 2 marca 2010 r. i 1 grudnia 2010 r.) przyjmuje wartości: 1, 2, 5-9.

${ }^{4} \mathrm{~W}$ dystrybucji ankiet pomagali uczestnicy seminarium dyplomowego realizowanego na kierunku Ekonomia (Wydział Nauk Ekonomicznych, Uniwersytet Warmińsko-Mazurski w Olsztynie): A. Arent, A. Buczyńska, M. Ceberek, P. Czamlet, K. Dziedzic, M. Giziewski, R. Gwozdowski, A. Karpińska, N. Mazalewska, D. Pawelczyk, A. Plewka, S. Radziul. 
metody EM (Expectation-Maximization) $)^{5}$. Jej idea sprowadza się do podziału zbioru $n$ obiektów na $K$ rozłącznych i niepustych podzbiorów, zwanych klasami, tak aby obiekty należące do tych samych klas były najbardziej podobne, a obiekty należące do różnych klas były najmniej podobne [Dziechciarz (red.) 2012]. Algorytm metody EM oblicza prawdopodobieństwa przynależności obserwacji do skupień przy założeniu jednego lub wielu rozkładów prawdopodobieństwa. Celem procedury jest maksymalizacja ogólnego prawdopodobieństwa (wiarygodności danych) dla danego grupowania. W odróżnieniu od podejść klasycznych algorytm EM może być stosowany zarówno do zmiennych ilościowych, jak i jakościowych [Migut 2009; Analiza skupień].

Podstawę grupowania stanowiły dwa wskaźniki obiektywne $\left(x_{1}\right.$ i $\left.x_{2}\right)$ oraz 7 cech subiektywnych: $y_{1}$ - ocena tematycznych obszarów koncentracji projektów europejskich zrealizowanych przez samorząd, $y_{2}$ - cele realizowanych przedsięwzięć, $y_{3}$ - ocena czynników branych pod uwagę przy podejmowaniu decyzji o ubieganie się o dofinansowanie z UE, $y_{4}$ - czynniki ułatwiające przygotowanie projektu unijnego i wypełnienie wniosku o dofinansowanie, $y_{5}$ - czynniki ułatwiające realizację projektu po podpisaniu umowy o dofinansowanie, $y_{6}$-czynniki utrudniające przygotowanie projektu unijnego i wypełnienie wniosku o dofinansowanie, $y_{7}$ - czynniki utrudniające realizację projektu po podpisaniu umowy o dofinansowanie.

Jako optymalny wariant klasyfikacji przyjęto podział 909-elementowego zbioru gmin, które wzięły udział w badaniu ankietowym na trzy skupienia zawierające gminy podobne do siebie pod względem struktury analizowanych elementów. Jako że celem grupowania było ustalenie podobieństwa pomiędzy obiektami, nie zaś ich hierarchizacja, oznaczenia przypisane skupieniom należy traktować jako umowne [Wojarska i in. 2015].

Do charakterystyki badanej zbiorowości i poszczególnych klas gmin wykorzystano podstawowe statystyki opisowe, w tym:

- w odniesieniu do danych ilościowych - średnią arytmetyczną, wartość maksymalną i minimalną, rozstęp, odchylenie standardowe, współczynnik zmienności; - w odniesieniu do danych jakościowych - wskaźnik ważności $\left(W_{w}\right)^{6}$ (przy analizie odpowiedzi respondentów na pytania skalowane) i wskaźnik struktury $\left(W_{s}\right)^{7}$ (w odniesieniu do wskazań tak-nie). Obydwa wskaźniki przyjmują wartości $<0 ; 1>$ i informują o tym, jaką część punktów maksymalnie możliwych do zdobycia ankietowani przyznali danej odpowiedzi.

\footnotetext{
${ }^{5}$ Klasyfikacja wykonana została za pomocą programu STATISTICA 12.

${ }^{6}$ Wskaźnik ważności $\left(W_{w}\right)$ wyznaczono wg formuły: $W_{w}=\Sigma\left(n_{i} \times w_{i} / k \times N\right)$, gdzie: $i$-indeks oceny; $n_{i}$ - liczba wskazań danego czynnika na $i$-tym miejscu; $k$ - maksymalna ocena w skali od 0 do $k$; $N$ - liczba respondentów, którzy udzielili odpowiedzi na pytanie; $w_{i}$ - ocena odpowiadająca miejscu czynnika $i$ [Kuzel 2005].

7 Wskaźnik struktury $\left(W_{s}\right)$ wyznaczono wg formuły: $W_{s}=n_{i} / N$, gdzie: $n_{i}-$ liczebność cząstkowa określająca, ile jednostek zbiorowości przypada na daną wartość cechy zmiennej, $N$ - liczebność zbiorowości [Zimny 2010].
} 


\section{Typologia gmin ze względu na wybrane aspekty problematyki funduszy UE}

Zastosowanie uogólnionej metody EM umożliwiło podział próby badawczej na trzy rozłączne i różnoliczne skupienia, oznaczone jako grupa I, II i III. Przestrzenny rozkład wyników klasyfikacji przedstawiony został na rysunku 1.

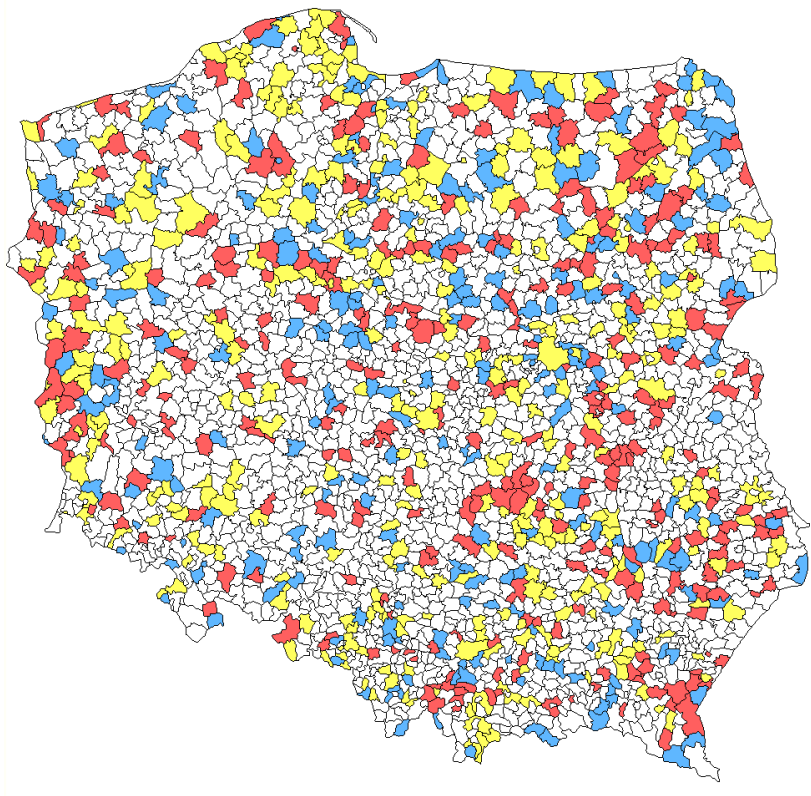

\begin{tabular}{l|c|c}
\multirow{2}{*}{ województwo } & \multicolumn{2}{c}{ liczba gmin } \\
\cline { 2 - 3 } & ogótem & próba \\
\hline dolnośląskie & 169 & 51 \\
\hline kujawsko-pomorskie & 144 & 62 \\
\hline lubelskie & 213 & 70 \\
\hline lubuskie & 83 & 39 \\
\hline lódzkie & 177 & 42 \\
\hline malopolskie & 182 & 63 \\
\hline mazowieckie & 314 & 135 \\
\hline opolskie & 71 & 16 \\
\hline podkarpackie & 160 & 60 \\
\hline podlaskie & 118 & 61 \\
\hline pomorskie & 123 & 60 \\
\hline śląskie & 167 & 50 \\
\hline świętokrzyskie & 102 & 53 \\
\hline warmińsko-mazurskie & 116 & 54 \\
\hline wielkopolskie & 226 & 52 \\
\hline zachodniopomorskie & 114 & 41 \\
\hline RAZEM & 2.479 & 909 \\
\hline grupa I & & \\
\hline & & \\
\hline & & \\
\hline & & \\
\hline & & \\
\hline
\end{tabular}

Rys. 1. Przestrzenny rozkład wyników klasyfikacji gmin z punktu widzenia doświadczeń w wykorzystaniu funduszy UE

Źródło: opracowanie własne.

Pierwsza, najliczniejsza grupa składała się z 357 gmin, a w jej strukturze 49,86\% stanowiły jednostki wiejskie, 27,73\% miejsko-wiejskie i 22,41\% miejskie. W zbiorze tym znalazły się m.in. najbardziej zaludnione miasta w Polsce: Warszawa, Kraków, Łódź, Wrocław, Poznań i Gdańsk. Samorządy zakwalifikowane do tego skupienia pozyskały łącznie ponad $3 / 4$ środków z puli przypadającej na całą próbę badawczą i razem zrealizowały 8231 projektów (głównie w ramach PROW - 36,27\% i PO KL-33,33\%).

Podstawowe statystyki wskaźników $x_{1}$ i $x_{2}$ dla zbioru I zestawione są w tabeli 1.

Z badań wynika, że projekty realizowane przez samorządy ze zbioru I dotyczyły głównie ${ }^{8}$ : edukacji publicznej $\left(W_{w}=0,76\right)$, kultury fizycznej i rekreacji $\left(W_{w}=0,75\right)$,

${ }^{8} \mathrm{~W}$ charakterystyce uwzględniono jedynie cechy, które spełniały warunek $W_{w}>0,5$ i $W_{s}>0,5$. 
Tabela 1. Wybrane statystyki dla wskaźników $x_{1}$ i $x_{2}$ (GRUPA I)

\begin{tabular}{|r|c|c|c|c|c|}
\hline Wskaźnik & $\max$ & $\overline{x_{k}}$ & $\min$ & $S_{k}$ & $v_{k}$ \\
\hline $\begin{array}{l}\text { Środki pozyskane przez samorząd gminny z UE } \\
\text { i innych programów zagranicznych per capita }\left(x_{1}\right)\end{array}$ & $5539,0 \mathrm{zł}$ & $1643,7 \mathrm{zl}$ & $113,4 \mathrm{zl}$ & $976,6 \mathrm{zl}$ & 0,59 \\
\hline $\begin{array}{l}\text { Środki pozyskane przez samorząd gminny z UE i } \\
\text { innych programów zagranicznych w dochodach } \\
\text { budżetów ogółem }\left(x_{2}\right)\end{array}$ & $16,27 \%$ & $6,10 \%$ & $0,47 \%$ & $3,17 \%$ & 0,52 \\
\hline
\end{tabular}

Objaśnienia: max - wartość maksymalna, $\overline{x_{k}}$ - średnia arytmetyczna, min - wartość minimalna, $S_{k}$ - odchylenie standardowe, $v_{k}$ - współczynnik zmienności.

Źródło: opracowanie własne.

wodociągów, kanalizacji i utrzymania porządku $\left(W_{w}=0,74\right)$, dróg gminnych i organizacji ruchu drogowego $\left(W_{w}=0,73\right)$, kultury $\left(W_{w}=0,71\right)$, ochrony środowiska i gospodarki wodnej $\left(W_{w}=0,68\right)$, turystyki $\left(W_{w}=0,63\right)$ oraz pomocy społecznej $\left(W_{w}=0,54\right)$. Podejmowane w ich ramach działania miały na celu: rozbudowę bądź modernizację infrastruktury podstawowej $\left(W_{s}=0,95\right)$, sportowo-rekreacyjnej i turystycznej $\left(W_{s}=0,87\right)$, poprawę jakości edukacji $\left(W_{s}=0,60\right)$, a także aktywizację lokalnej społeczności $\left(\mathrm{W}_{\mathrm{s}}=0,54\right)$.

Cechą charakterystyczną grupy I była bardzo duża liczba czynników, które ankietowani uznali za kluczowe przy podejmowaniu decyzji o ubieganie się o dofinansowanie unijne (11). Na liście tej znalazły się: konieczność rozwiązania problemu istotnego dla gminy $\left(W_{w}=0,95\right)$, potencjał gminy i możliwości jej rozwoju $\left(W_{w}=\right.$ $0,91)$, znaczenie inwestycji $\left(W_{w}=0,88\right)$, założenia wieloletniego planu inwestycyjnego $\left(W_{w}=0,86\right)$, sugestie zgłaszane przez mieszkańców $\left(W_{w}=0,85\right)$, założenia strategii rozwoju $\left(W_{w}=0,85\right)$, potrzeby jednostek organizacyjnych $\left(W_{w}=0,79\right)$, wymogi prawodawstwa unijnego i krajowego $\left(W_{w}=0,65\right)$, potrzeby organizacji pozarządowych $\left(W_{w}=0,65\right)$ i przedsiębiorców $\left(W_{w}=0,64\right)$ oraz dogodne terminy składania dokumentacji projektowej $\left(W_{w}=0,56\right)$.

Za główne czynniki sukcesu gwarantujące podpisanie umowy o dofinansowanie i sprawną realizację projektu uznano w tej grupie doświadczenie oraz przygotowanie merytoryczne pracowników urzędu gminy. W fazie przygotowawczej projektu wyznaczone dla nich wskaźniki struktury wyniosły 0,90 (dla doświadczenia) i 0,53 (dla kwalifikacji), a na etapie wdrażania projektu $-0,92$ i 0,77 .

Z kolei największą uciążliwość, zarówno na etapie przygotowywania wniosku o dofinansowanie, jak i właściwej realizacji projektu, stanowiła nadmierna formalizacja i biurokracja ( $W_{s}$ dla etapu początkowego wyniósł 0,71 , a wdrożeniowego 0,67). Dodatkowo niemal co drugi respondent z tej grupy jako czynnik utrudniający sprawną realizację projektu unijnego (po podpisaniu umowy o dofinansowanie) potraktował znalezienie dobrego wykonawcy $\left(W_{s}=0,53\right)$.

Następna, wyodrębniona za pomocą uogólnionej metody EM grupa składała się z 310 gmin i na tle dwóch pozostałych skupień wyróżniała się m.in. wysokim odset- 
kiem gmin wiejskich (70,0\%), najniższymi wartościami średnich dla wskaźników $x_{1}$ i $x_{2}$ (tab. 2) oraz najniższą alokacją środków unijnych $(9,51 \%$ kwoty pozyskanej przez gminy z próby badawczej). Z uwagi na dominację gmin wiejskich, w strukturze źródeł finansowania projektów zrealizowanych przez samorządy z tej grupy największy udział miał PROW (57,52\%).

Tabela 2. Wybrane statystyki dla wskaźników $x_{1}$ i $x_{2}$ (GRUPA II)

\begin{tabular}{|l|c|c|c|c|c|}
\hline \multicolumn{1}{|c|}{ Wskaźnik } & $\max$ & $\overline{x_{k}}$ & $\min$ & $S_{k}$ & $v_{k}$ \\
\hline $\begin{array}{l}\text { Środki pozyskane przez samorząd gminny z UE } \\
\text { i innych programów zagranicznych per capita }\left(x_{1}\right)\end{array}$ & $4321,0 \mathrm{zł}$ & $1254,2 \mathrm{zł}$ & $95,2 \mathrm{zł}$ & $697,1 \mathrm{zł}$ & 0,56 \\
\hline $\begin{array}{l}\text { Środki pozyskane przez samorząd gminny z UE } \\
\text { i innych programów zagranicznych w dochodach } \\
\text { budżetów ogółem }\left(x_{2}\right)\end{array}$ & $13,13 \%$ & $4,98 \%$ & $0,45 \%$ & $2,46 \%$ & 0,49 \\
\hline
\end{tabular}

Objaśnienia jak w tabeli 1.

Źródło: opracowanie własne.

Cechą odróżniającą skupienie II od pozostałych dwóch zbiorów były także najniższe wartości wskaźników ważności i struktury wyznaczone dla zmiennych ilościowych $\left(y_{1}-y_{7}\right)$. W efekcie przełożyło się to na najmniejszą liczbę cech spełniających warunek $W>0,5$ i tym samym uwzględnionych przy opisie tej grupy.

$\mathrm{Z}$ analizy wynika, że obszarem, w którym samorządy z tego zbioru najczęściej inwestowały pozyskane środki europejskie, były wodociągi i zaopatrzenie w wodę, usuwanie i oczyszczanie ścieków komunalnych, utrzymanie czystości i porządku oraz urządzeń sanitarnych $\left(W_{w}=0,54\right)$. Realizowane przedsięwzięcia miały najczęściej charakter infrastrukturalny i ukierunkowane były na rozbudowę lub modernizację infrastruktury podstawowej $\left(W_{s}=0,86\right)$ oraz rozbudowę lub modernizację infrastruktury sportowo-rekreacyjnej i turystycznej $\left(W_{s}=0,72\right)$.

Aktywność projektowa gmin determinowana była koniecznością rozwiązania problemu istotnego dla gminy $\left(W_{w}=0,76\right)$, potencjałem gminy i możliwościami jej rozwoju $\left(W_{w}=0,63\right)$, założeniami strategii rozwoju $\left(W_{w}=0,62\right)$, sugestiami zgłaszanymi przez mieszkańców $\left(W_{w}=0,62\right)$, założeniami wieloletniego planu finansowego $\left(W_{w}=0,61\right)$ i oddziaływaniem inwestycji mającej powstać $\mathrm{w}$ wyniku realizacji projektu $\left(W_{w}=0,54\right)$.

Wśród czynników ułatwiających pozyskanie środków unijnych i wdrożenie projektu na pierwszy plan (podobnie jak w grupie I) wysunęło się doświadczenie w aplikowaniu o środki europejskie $\left(W_{s}=0,74\right)$ oraz doświadczenie w realizacji projektów $\left(W_{s}=0,82\right)$. Ponadto często wymienianym przez respondentów ułatwieniem w zakresie przygotowania projektu i wypełnienia wniosku o dofinansowanie były pilne potrzeby inwestycyjne gminy $\left(W_{s}=0,56\right)$, a na etapie wdrażania projektu kwalifikacje pracowników urzędu $\left(W_{s}=0,62\right)$. 
Jeśli chodzi o utrudnienia, to najczęściej wskazywany był, tak samo jak w grupie I, duży stopień zbiurokratyzowania procedur. Wyznaczone dla tej cechy wskaźniki struktury wyniosły odpowiednio 0,58 (na etapie przygotowań) i 0,51 (w fazie realizacji projektu).

Ostatnia wyłoniona w wyniku klasyfikacji grupa gmin składała się z 242 jednostek i swoją strukturą (wg typów gmin) najlepiej odzwierciedlała strukturę całej próby. Podobnie jak w dwóch pozostałych skupieniach największy odsetek stanowiły tu samorządy wiejskie $(61,98 \%)$, następnie miejsko-wiejskie $(25,62 \%)$ i miejskie $(12,40 \%)$. Także i w tym przypadku największa liczba projektów została sfinansowana ze środków PROW (49,85\%). Na tle dwóch pozostałych zbiorów grupa ta wyróżniała się największym zróżnicowaniem (ocenionym na bazie współczynników zmienności), najwyższą średnią i największą wartością rozstępu dla obu wskaźników ilościowych $\left(x_{1}\right.$ i $\left.x_{2}\right)$ (tab. 3 ). W jej skład weszło 10 pierwszych samorządów $\mathrm{z}$ najwyższymi wartościami absorpcji środków unijnych per capita oraz wielkości alokacji funduszy w dochodach ogółem.

Tabela 3. Wybrane statystyki dla wskaźników $x_{1}$ i $x_{2}$ (GRUPA III)

\begin{tabular}{|l|c|c|c|c|c|}
\hline \multicolumn{1}{|c|}{ Wskaźnik } & $\max$ & $\overline{x_{k}}$ & $\min$ & $S_{k}$ & $v_{k}$ \\
\hline $\begin{array}{l}\text { Środki pozyskane przez samorząd gminny z UE } \\
\text { i innych programów zagranicznych per capita }\left(x_{1}\right)\end{array}$ & $24103,3 \mathrm{zł}$ & $1867,3 \mathrm{zł}$ & $87,9 \mathrm{zł}$ & $2394,0 \mathrm{zł}$ & 1,3 \\
\hline $\begin{array}{l}\text { Środki pozyskane przez samorząd gminny z UE } \\
\text { i innych programów zagranicznych w dochodach } \\
\text { budżetów ogółem }\left(x_{2}\right)\end{array}$ & $42,04 \%$ & $6,43 \%$ & $0,38 \%$ & $5,03 \%$ & 0,78 \\
\hline
\end{tabular}

Objaśnienia jak w tabeli 1.

Źródło: opracowanie własne.

Środki unijne pozyskane przez samorządy gminne ze skupienia III przeznaczane były najczęściej na współfinansowanie projektów z zakresu wodociągów, kanalizacji i utrzymania porządku $\left(W_{w}=0,67\right)$, edukacji publicznej $\left(W_{w}=0,60\right)$, kultury fizycznej i rekreacji $\left(W_{w}=0,59\right)$, ochrony środowiska i gospodarki wodnej $\left(W_{w}=0,58\right)$, kultury $\left(W_{w}=0,54\right)$ oraz drogownictwa $\left(W_{w}=0,52\right)$. Cele tych przedsięwzięć, a także hierarchia ich ważności (pomimo niewielkich różnic w wartościach wskaźników struktury) były identyczne, jak w grupie I. Oznacza to, że projekty europejskie realizowane przez gminy z grupy III ukierunkowane były na rozbudowę lub modernizację infrastruktury podstawowej $\left(W_{s}=0,92\right)$, sportowo-rekreacyjnej i turystycznej $\left(W_{s}=0,81\right)$, poprawę jakości edukacji $\left(W_{s}=0,63\right)$ oraz aktywizację lokalnej społeczności $\left(W_{s}=0,53\right)$.

Duże podobieństwo do grupy I było także widoczne w odniesieniu do czynników branych pod uwagę przy podejmowaniu decyzji o ubieganie się o dofinansowanie unijne. Największe znaczenie dla respondentów z gmin zbioru III miały: konieczność rozwiązania problemu istotnego dla gminy $\left(W_{w}=0,91\right)$, potencjał gmi- 
ny i możliwości jej rozwoju $\left(W_{w}=0,80\right)$, znaczenie inwestycji mającej powstać w wyniku realizacji projektu ( $\left.W_{w}=0,76\right)$, założenia wieloletniego planu inwestycyjnego $\left(W_{w}=0,73\right)$, sugestie zgłaszane przez mieszkańców gminy $\left(W_{w}=0,70\right)$, założenia strategii rozwoju $\left(W_{w}=0,70\right)$, potrzeby jednostek organizacyjnych gminy $\left(W_{w}=0,66\right)$, odpowiednie terminy składania dokumentacji projektowej do instytucji wdrażającej $\left(W_{w}=0,54\right)$ i konieczność dostosowania wybranych obszarów do wymagań przepisów krajowych lub unijnych $\left(W_{w}=0,52\right)$.

Niewielkie odmienności w stosunku do pozostałych grup pojawiły się w zakresie czynników ułatwiających przygotowanie projektu i wypełnienie wniosku o dofinansowanie. Choć na pierwszym miejscu (tak jak w poprzednich zbiorach) wymieniane było doświadczenie $\mathrm{w}$ aplikowaniu o fundusze $\left(W_{s}=0,86\right)$, a na trzecim pilne potrzeby inwestycyjne gminy $\left(W_{s}=0,57\right)$, to dwa pozostałe ułatwienia, dla których $W_{s}>0,5$, były całkowitą nowością. Ankietowani reprezentujący gminy skupienia III relatywnie częściej od pozostałych jako ułatwienie traktowali pozytywne nastawienie wójta/burmistrza/prezydenta miasta $\left(W_{s}=0,62\right)$ oraz szkolenia organizowane przez instytucję wdrażającą $\left(W_{s}=0,53\right)$. Z kolei wśród czynników ułatwiających realizację projektu po podpisaniu umowy o dofinansowanie wymieniano, tak samo jak w poprzednich skupieniach, doświadczenie we wdrażaniu tego typu przedsięwzięć $\left(W_{s}=0,92\right)$ i przygotowanie merytoryczne członków zespołu projektowego $\left(W_{s}=0,68\right)$.

Największe różnice pomiędzy grupą III a pozostałymi dwoma skupieniami pojawiły się natomiast w przypadku barier. Przejawiały się one zarówno w większej liczbie cech, które uzyskały powyżej 50\% wskazań, jak i w wyższych wartościach współczynników $W_{s}$. Do czynników utrudniających sprawne opracowywanie założeń projektowych i przygotowanie niezbędnej dokumentacji, oprócz biurokracji i formalizacji $\left(W_{s}=0,88\right)$, zaliczono tu także: obciążanie pracowników oddelegowanych do prac nad projektem dodatkowymi obowiązkami $\left(W_{s}=0,66\right)$, często zmieniające się wytyczne i zapisy podstawowych dokumentów $\left(W_{s}=0,55\right)$ i zbyt krótki czas na przygotowanie dokumentacji $\left(W_{s}=0,51\right)$. Z kolei wśród czynników spowalniających prace projektowe po podpisaniu umowy o dofinansowanie, poza nadmiernym sformalizowaniem procedur $\left(W_{s}=0,86\right)$, wymieniano również: nadmierne obciążenie osób zaangażowanych $\mathrm{w}$ realizację projektu innymi obowiązkami $\left(W_{s}=0,70\right)$, długi okres weryfikacji wniosków o płatność $\left(W_{s}=0,60\right)$, niewielkie możliwości wprowadzania zmian do projektu $\left(W_{s}=0,58\right)$, znalezienie dobrego wykonawcy $\left(W_{s}=0,54\right)$ oraz niejednolitość interpretacji przepisów i niemożność uzyskania wiążących decyzji w tym zakresie $\left(W_{s}=0,54\right)$.

\section{Zakończenie}

Rozważania podejmowane w artykule ukierunkowane były na identyfikację typów gmin z punktu widzenia wybranych aspektów problematyki funduszy UE. Z założenia wyodrębnione grupy powinny różnić się między sobą ze względu na strukturę zmiennych stanowiących podstawę klasyfikacji. Analiza wykazała, że różnice te do- 
tyczyły przede wszystkim zmiennych ilościowych (wskaźników $x_{1}$ i $x_{2}$ ) i w mniejszym stopniu cech jakościowych $\left(y_{1}-y_{7}\right)$. W przypadku tych drugich, grupy różniły się między sobą nie tyle hierarchią cech (choć oczywiście były tu pewne różnice), ile wartością wyznaczonych dla nich wskaźników ważności i struktury (najwyższe pojawiały się zbiorze I, najniższe w II). W przypadku grupy II niskie wartości współczynników dały w efekcie najmniej liczny zbiór cech cząstkowych kwalifikujących się $^{9}$ do uwzględnienia przy charakterystyce zbioru (w sumie było ich 15, podczas gdy w grupie I 30, a w III aż 35). Grupa II wyróżniała się także ze względu na najniższą średnią wartość absorpcji środków unijnych per capita i najmniejszy udział tych środków w dochodach ogółem budżetów gmin (najwyższe osiągnęła grupa III).

Najbardziej zróżnicowane odpowiedzi pomiędzy poszczególnymi skupieniami pojawiły się w odniesieniu do tematycznych obszarów zrealizowanych przedsięwzięć, czynników ułatwiających przygotowanie projektu i wypełnienie wniosku o dofinansowanie oraz barier towarzyszących wdrażaniu projektu. Z kolei największa (100\%) zgodność dotyczyła czynników ułatwiających realizację projektu po podpisaniu umowy o dofinansowanie.

\section{Literatura}

Analiza skupień, Internetowy podręcznik statystyki, http://www.statsoft.pl/textbook/stathome_stat. html?http\%3A\%2F\%2Fwww.statsoft.pl\%2Ftextbook\%2Fstcluan.html (15.03.2016).

Churski P., Perdał R., Herodowicz T., 2016, Rola środków polityki spójności pozyskiwanych przez samorzą terytorialny w rozwoju społeczno-gospodarczym ośrodków regionalnych w Polsce, Samorząd Terytorialny, nr 7-8, s. 96-115.

Dziechciarz J. (red.), 2012, Ekonometria. Metody, przyktady, zadania, Wyd. UE we Wrocławiu, Wrocław.

Kuzel M., 2005, Wspótpraca przedsiębiorstw ze zlokalizowanymi w Polsce filiami światowych korporacji-wyniki badania ankietowego, www.skolar.umk.pl/pdf/Kuzel_Badanie_2005_2.pdf.

Migut G., 2009, Zastosowanie technik analizy skupień do i drzew decyzyjnych do segmentacji rynku, http://www.statsoft.pl/Portals/0/Downloads/Zastosowanie_technik.pdf (28.02.2016).

Misiąg J., Misiąg W., Tomalak M., 2013, Ocena efektywności wykorzystania pomocy finansowej Unii Europejskiej jako instrumentu polityki spójności spoteczno-gospodarczej oraz poprawy warunków życia, Wyd. WSIiZ w Rzeszowie, Rzeszów.

Swianiewicz P., 2015, Absorpcja funduszy strukturalnych przez samorzady - doświadczenia z lat 2007-2013, Finanse Komunalne, nr 1-2, s. 7-21.

Wakuła M., 2009, Wybrane problemy zarzadzania finansami gmin, Zeszyty Naukowe Akademii Podlaskiej w Siedlcach, Seria Administracja i Zarządzanie, nr 82, s. 109-120.

Wojarska M., Marks-Bielska R., Babuchowska K., 2015, Instytucje otoczenia biznesu w województwie warmińsko-mazurskim - próba typologii z uwzględnieniem konkurencyjności i innowacyjności, Europa Regionum, t. XXII, s. 227-245.

Wojciechowski E., 2012, Ekonomiczne oblicze samorzadu terytorialnego, [w:] Dylewski M. (red.), Finanse i ryzyko w ksztaltowaniu rozwoju regionu, Zeszyty Naukowe Wyższej Szkoły Bankowej w Poznaniu, nr 41, Wyd. WSB w Poznaniu, Poznań, s. 201-210.

9 Tzn. spełniających warunek $\mathrm{W}>0,50$. 
Wyszkowska D., 2010, Pozyskiwanie środków pomocowych Unii Europejskiej przez gminy województwa podlaskiego, Gospodarka Narodowa, nr 10, s. 97-112.

Wyszkowska D., 2011, Efektywność wykorzystania funduszy pomocowych Unii Europejskiej przez jednostki samorzadu terytorialnego, Zeszyty naukowe Uniwersytetu Szczecińskiego, nr 687, s. 309-318.

Zawora J., 2014, Sytuacja dochodowa samorząów gminnych w Polsce, [w:] Sokołowski J., Sosnowski M. (red.), Finanse publiczne, Prace Naukowe UE, nr 346, Wyd. UE we Wrocławiu, Wrocław, s. $368-376$.

Zimny A., 2010, Statystyka opisowa. Materiały pomocnicze do ćwiczeń. Wydanie drugie zmienione, Wyd. PWSZ w Koninie, Konin.

www.mojapolis.pl (28.02.2016). 